\title{
Revista de Filología y Lingüística de la Universidad de Costa Rica
}

Publicación Semestral, EISSN: 2215-2628

Volumen 47 - 1

Enero 2021 - Junio 2021

\section{García Márquez: el periodismo hiperbólico y la invención del diarismo mảgico}

\author{
Néfer Muñoz Solano
}

Muñoz Solano, N. (2021). García Márquez: el periodismo hiperbólico y la invención del diarismo mágico. Revista de Filología y Lingüística de la Universidad de Costa Rica, 47(1), e44439. doi: https://doi.org/10.15517/rfl.v47i1.44439

\section{(9) $(1) \Theta \Theta$}

Doi: https://doi.org/10.15517/rfl.v47i1.44439

URL: https://revistas.ucr.ac.cr/index.php/filyling/index 


\section{García Márquez: Hyperbole in Journalism and The Invention of Magical Journalism}

\section{Muñoz Solano, Néfer}

\author{
(iD) Néfer Muñoz Solano \\ nmunozsolano@udallas.edu \\ Profesor del Departamento de Lenguas Modernas, \\ Universidad de Dallas, Irving, Estados Unidos
}

\author{
Revista de Filología y Lingüística de la Universidad \\ de Costa Rica \\ Universidad de Costa Rica, Costa Rica \\ ISSN: 0377-628X \\ ISSN-e: $2215-2628$ \\ Periodicidad: Semestral \\ vol. 47 , núm. 1,2021 \\ filyling@gmail.com
}

Recepción: 06 Mayo 2020

Aprobación: 23 Junio 2020

URL: http://portal.amelica.org/ameli jatsRepo/125/1251597036/index.htm

DOI: https://doi.org/10.15517/rfl.v47i1.44439
Resumen: Este artículo investiga las imbricaciones y porosidades entre la ficción y la no ficción en los textos tempranos de prensa de Gabriel García Márquez. Este trabajo propone un proceso fluido de intercambios de doble vía entre los discursos informativos y los de creación literaria, donde el joven escritor experimenta para novelar dentro del periodismo, haciendo uso de la hipérbole y de personajes o situaciones ficticias para articular un fenómeno denominado el diarismo mágico. El empleo de la hipérbole en García Márquez funciona como un resorte de intensiones (con "s") e intenciones (con "c") para expandir o comprimir los contenidos semánticos. El escritor periodista construye sus hipérboles con dos características: la exageración de detalles y la precisión en las exageraciones. Por un lado, las hipérboles pretenden desbordar e ir más allá de los límites y, por otro, gracias a la descripción y la enumeración detalladas, este desbordamiento es controlado y tiene como objetivo hacer que sus imágenes resulten creíbles en el contexto de las historias que cuenta.

Palabras clave: García Márquez, literatura, periodismo, imbricaciones, diarismo mágico.

Abstract: This article investigates the overlap and porosities between fiction and non-fiction discourses in the early texts of Gabriel García Márquez. I propose there is a fluid process of exchange between informative discourses and those of literary creation, where the young writer experimented to novel within journalism, using hyperbole as well as fictional situations and characters in a phenomenon that I call magical journalism. García Márquez's use of hyperboles works as a springboard of tensions and intentions to expand and compress semantic content. The writer-journalist constructs hyperboles using two main elements: superfluous detail and precise descriptions. On the one hand, hyperboles overflow, pressing limits and, on the other, intricate detailing controls the excess, rendering images credible in the context of the stories that are told.

Keywords: García Márquez, literature, journalism, imbrications, magical journalism. 


\section{INTRODUCCIÓN}

En 1950, Gabriel García Márquez, entonces con 23 años, se sentaba día tras día, en medio del sofocante calor del Caribe, frente a una máquina de escribir Underwood. Con el seudónimo de "Septimus", el joven periodista escribía en El Heraldo de Barranquilla una columna llamada La Jirafa, un espacio donde vertía sus comentarios sobre noticias insólitas, cables internacionales y personajes de la ciudad, alternando --y en ocasiones mezclando- la realidad con la ficción. Su sección se imprimía regularmente sin problemas, pero una mañana ocurrió un imprevisto en los talleres del periódico y, por un error de impresión, la columna del 29 de mayo salió borrosa y apenas podía leerse con dificultad ${ }^{1}$.

En esa columna nebulosa, García Márquez contaba la historia de un personaje de un pueblo del Caribe, el hijo de una familia de cinco generaciones de zapateros. El texto detallaba cómo al crecer, para deshonra y escándalo de su familia, el muchacho había anunciado a su parentela que no quería dedicarse al oficio familiar de reparar zapatos y avisaba que prefería ser músico, específicamente trompetista. A pesar del disgusto de sus familiares, el joven persistió, logró su sueño y se consagró en el arte de interpretar una sola pieza. Una vez al año, por el resto de su vida, se convirtió en el centro de atención -y de admiración- cuando conmovedoramente interpretaba en su pueblo, en un solo para trompeta, el himno nacional. Años después, la familia de zapateros decidió levantarle una estatua a quien anteriormente habían vituperado por su decisión vocacional. La nota periodística cierra con un juego de palabras (muy garciamarquiano), ya que la estatua iba a tener como inscripción una dedicatoria en la que los zapateros le agradecían a su pariente trompetista ser la causa de que el autor del himno nacional hubiera encontrado "la horma de sus zapatos" (García Márquez, 1991 b, p. 235). Escrita con un tono similar al de un cuento, sin mencionar nunca el nombre del trompetista, esta columna, visualmente casi ilegible para los lectores de El Heraldo, es un texto sobre la búsqueda de la identidad personal, el derecho a disentir y el peso de la tradición y la familia, pero también remite a una contienda entre la autodeterminación y los moldes sociales, entre la voluntad individual y la imposición colectiva. Este texto es, además, un ejemplo -literal- de los contactos borrosos y de las fronteras nebulosas entre la ficción y la no ficción en la tradición literaria latinoamericana.

En la historia de las letras de América Latina, desde la colonia hasta el siglo XXI, es común encontrar a la figura del "escritor periodista", el literato que trabaja como reportero en salas de redacción. Esta figura, quien mezcla, traslapa e hibrida discursos, no comienza ni termina con García Márquez, pero sí encuentra en él a uno de sus exponentes más visibles y prominentes. En este grupo se cuentan nombres como José Joaquín Fernández de Lizardi, José Martí, Rubén Darío, Roberto Arlt, Lima Barreto, Jorge Amado y Elena Poniatowska, solo para citar algunos ejemplos. Además, hay que mencionar que en este contexto las columnas de García Márquez forman parte de una larga tradición de la crónica periodística latinoamericana, que ha combinado historias reales con la ficción, y de la que forman parte numerosos autores, por ejemplo, el peruano Ricardo Palma.

Como lo apunta el crítico Pablo Calvi, hay que recordar que parte de las literaturas fundacionales de América Latina no fueron concebidas originalmente como libros, sino que fueron publicadas en la prensa y por eso es que si la materialidad del canon original latinoamericano está en los diarios y periódicos, hay que tener en perspectiva que muchos de estos trabajos se publicaron por entregas y compartieron páginas con otros tipos de textos (2019, p. 5). Una de las formas de escritura dentro de los periódicos tradicionalmente más practicada por muchos escritores ha sido la crónica, un género que mezcla y combina características del artículo, el comentario, la entrevista, el perfil, el ensayo autobiográfico y la nota de viajes, es decir, es un género puente entre el periodismo y la literatura (Martin, 2012, p. 16). En el caso específico de García Márquez, el crítico Pedro Sorela dice que su obra periodística es paralela a su obra de creación y no se puede comprender a fondo una sin una lectura cercana de la otra $(1988$, p. 53). Sin embargo, es importante apuntar que no solo son paralelas, sino que además están imbricadas y hay momentos de zigzagueos constantes entre la ficción y la no ficción. 
A finales de la década de 1940 y durante los primeros años del siguiente decenio, el joven García Márquez trabajó y escribió a tiempo completo en momentos sucesivos en periódicos del Caribe de Colombia, en $E l$ Universal de Cartagena y El Heraldo de Barranquilla. Esa inmersión en el periodismo, como lo explica el crítico Raymond Leslie Williams, benefició posteriormente a sus novelas, no porque le haya permitido un "contacto con la realidad", sino porque en las salas de redacción el escritor comenzó a experimentar con una variedad de estilos, técnicas y géneros (1984, p. 134). El propio García Márquez le confesaría a su amigo Plinio Apuleyo Mendoza que en sus novelas usó "recursos" periodísticos para darle validez a sus historias, como la precisión de los detalles (Mendoza, 1982, p. 44).

$\mathrm{Al}$ analizar esas historias y textos de García Márquez, la crítica ha señalado ampliamente a la hipérbole como uno de los tropos más sobresalientes. El crítico y escritor Ariel Dorfman ha apuntado que las novelas del colombiano buscan trascender los límites de lo que convencionalmente es conocido como realidad (1991, p. 20); Claudio Guillén ha señalado que la hiperbolización de sucesos y personajes, que se nota claramente en Cien años de soledad, crea una realidad desbordante (2007, p. CX); y, dentro de esa realidad, como lo explica Erik Camayd-Freixas, la figura retórica de la hipérbole, al deslizar acontecimientos prodigiosos, paradójicamente, refuerza la verosimilitud (1998, p. 260). En este sentido, el crítico Philip Swanson afirma que García Márquez invita a sus lectores a ver una realidad que trasciende lo racional, de manera que situaciones como el ascenso al cielo de una joven, la levitación de un sacerdote después de tomar chocolate o una lluvia de mariposas amarillas son presentadas como algo perfectamente natural, mientras que objetos como el hielo, los imanes, las fotografías o los trenes se presentan como algo inimaginablemente extraño (Swanson, 2017).

En los textos tempranos de prensa de García Márquez se aprecia cómo el joven escritor ficcionalizó personajes, lugares y situaciones. En este trabajo argumento que en sus primeros años García Márquez comenzó a articular un proceso fluido de doble vía que va a estar presente durante toda su producción escrituraria: novelar dentro del periodismo y reportear en la novela. En esa primera época, el joven escritor ficcionalizó en sus textos periodísticos y recabó información que más adelante usaría en sus novelas. Su cercano colaborador Jaime Abello Banfi ha escrito cómo esta primera etapa de su carrera está marcada por una "creatividad sin límites", en la que sus editores le permitieron incluir "licencias literarias" en sus piezas periodísticas y en las que comenzó a delinear sus personajes de Macondo (2017, p. 179). De manera recíproca, en un proceso de ida y vuelta, García Márquez llegó a aplicar prácticas comunes en los diarios en la escritura de sus novelas. Este trabajo se concentra específicamente en la primera parte de ese fenómeno, en el proceso de ficcionalización dentro de las salas de redacción y los periódicos. En los escritos tempranos de García Márquez ya se nota esa fuerza narrativa impulsada por los tropos de la desmesura, el desafuero y el exceso que, si bien agrietan el realismo de sus escritos, se constituyen -al mismo tiempo- en artificios que les otorgan verosimilitud, y articulan un periodismo hiperbolizado y ficcional que aquí denomino el diarismo mágico².

En este trabajo sostengo que el empleo de la hipérbole en García Márquez funciona como un resorte de intensiones (con "s") e intenciones (con " $c$ ") para expandir o comprimir los contenidos semánticos. El periodista escritor construye sus hipérboles con dos características: la exageración de detalles y la precisión en las exageraciones. Es decir, por un lado, las hipérboles pretenden desbordar e ir más allá de los límites y, por otro, gracias a la descripción y la enumeración detalladas, este desbordamiento es controlado y tiene como objetivo hacer que sus imágenes resulten creíbles en el contexto de las historias que cuenta. El diarismo mágico emplea a la hipérbole detallada para contar una historia, no solamente en el sentido de "narrar" sino también de "enumerar" elementos, lo que provoca una acumulación y un hacinamiento de datos fácticos, que en una relación directa con el sensacionalismo pretende captar la atención de los lectores, así como informar y entretener. El empleo de la hipérbole en el periodismo, así como la ficcionalización de datos, son estrategias narrativas del joven García Márquez que conllevan una complicidad doble: por un lado, la del aparato de filtros y censores dentro de la cadena de producción del periódico y, por otro, la de su público lector, que puede abrazar -o rechazar- con su credulidad los textos y las exageraciones. 


\section{LA JiRAFA HIPERBóLICA Y FICCIONALIZADA}

El 30 de mayo de 1950, un día más tarde de la impresión nebulosa de su columna sobre el trompetista, García Márquez aprovechó el contratiempo de los talleres de impresión de El Heraldo para convertirlo en el tema principal de su columna La Jirafa, al asegurar hiperbólicamente en un tono de broma que el texto borroso de la víspera era "una jirafa invisible" (1991b, p. 236) ${ }^{3}$. García Márquez tituló a esa columna "La peregrinación de la jirafa" y en ella explicaba el proceso de escritura y la peregrinación que vivían sus escritos dentro del periódico. Según contaba, su texto primigenio era "vulnerable a los más imperceptibles resortes editoriales" (García Márquez, 1991b, p. 235), ya que una vez salido del rodillo de su máquina, pasaba por una travesía de mudanzas estilísticas, intelectuales y tecnológicas, yendo de mano en mano dentro de aquella empresa de información, transformándolo hasta salir a la calle a la mañana siguiente convertido en una columna dentro de las páginas del diario.

En "La peregrinación de la Jirafa", al describir esa cadena de filtros, el autor asegura que su columna es un "animal indefenso, que puede romperse una coyuntura a la vuelta de cualquier esquina" (García Márquez, 1991b, p. 235). Es decir, García Márquez quiere dotar a su escritura individual de vida propia, pero reconoce que una característica central de sus textos es su fragilidad, ya que su columna puede ser objeto de ediciones parciales o totales, ya sea por la autocensura (al seguir los lineamientos de un estilo periodístico que borra la individualidad), ya sea por la voluntad directa de los editores (que modifican deliberadamente el texto), o como en La Jirafa borrosa, por los imprevistos de un accidente tecnológico de reproducción. En cualquiera de los casos, el resultado es la misma consecuencia, la contingencia de que su voz autoral quede invisible.

Cuando García Márquez describe a esta cadena de filtros metafóricamente como “resortes”, propone de manera tácita que no son rígidos por completo, sino que funcionan como un muelle, con una condición elástica, aplicando su fuerza de control con mayor o menor medida dependiendo de cada texto y del contexto social, económico y político. Implícitamente, el escritor está subrayando también los intereses comerciales e ideológicos en la estructura de funcionamiento de los periódicos, ya que un "resorte" es "un medio material o inmaterial” para lograr un fin (Real Academia Española, 2019c). En esta descripción de sí mismo como escritor dentro de una sala de redacción hay una tensión similar a la historia del trompetista con su familia en su columna anterior, pero en este caso es una contienda entre la imposición editorial del periódico y su voz de autor, entre los moldes periodísticos y su autodeterminación como literato. Al analizar los textos de prensa del joven García Márquez, se constata que en esa tensión por la escritura de su periodismo el desbordamiento de su inventiva ganó en muchas ocasiones y se tradujo en un lenguaje hiperbólico.

La palabra "hipérbole" proviene del étimo latino hyperbŏle, y este, a su vez del griego yperboli, que puede designar una "exageración”, una "curva geométrica” o el acto de "pasar una montaña”; en griego, está compuesta de dos partes, el prefijo huper, que significa "sobre", "exceso" o "movimiento hacia arriba", y el verbo ballein que quiere decir "lanzar" y "disparar" (Bampiniōtēs, 2002, p. 343). En el sentido de disparo se derivan palabras como "balística" y "bólido", que tienen que ver con la idea de lanzar o arrojar algo (Moliner, 2007, p. 344). Como se puede advertir en su etimología, conceptualmente la hipérbole tiene que ver con un efecto para aumentar o disminuir, para disparar las características de un objeto, una persona o una situación. Es decir, hay una relación entre intensión (con "s") e intención (con "c"), ya que el hablante o narrador muestra una voluntad o una intencionalidad por intensificar y sobrepasar los límites, abriendo una brecha en el significado entre lo que es dicho (lo lingüístico) y lo que en realidad es (lo extralingüístico).

Es así como la hipérbole es entonces más de algo y lo que ese más implica depende del contenido semántico de la expresión literal. En el caso de la hipérbole de García Márquez, ese “algo de más”, añadido por el escritor, tiene como función interesar a sus lectores, ya que, como lo explica Claudia Claridge, una de las funciones de la hipérbole es captar efectivamente la atención de aquellos a quienes va dirigida (2011, p. 9). Aquí hay una carga ética, política, estética y social, ya que "captar efectivamente" la atención puede reforzar, o no, actitudes consumistas y acríticas. García Márquez no está ajeno a los valores comerciales que rigen a la prensa 
y sus textos periodísticos también están motivados por un afán de ser leído que, en el contexto de los diarios, conlleva la venta y el consumo de ejemplares.

Décadas más tarde, cuando ya era un escritor reconocido y había recibido el Premio Nobel de Literatura, García Márquez escribió que "en periodismo, un solo dato falso desvirtúa a los otros datos verídicos" y que por eso en los textos periodísticos "hay que apegarse a la verdad, aunque nadie la crea" (1991a, p. 97). Esta afirmación la hizo en una columna de 1981, titulada “¿Quién cree a Janet Cooke?”, en la cual se refería a un caso que en aquel momento había provocado un escándalo en el periodismo de los Estados Unidos. Janet Cooke era una periodista del Washington Post, quien había publicado un reportaje titulado "Jimmy's World" ("El mundo de Jimmy"), en el que se describía la vida de un niño de ocho años adicto a la heroína. El reportaje sobre las condiciones de vida de aquel niño adicto conmovió a la ciudad de Washington D.C. y por su texto Cooke recibió un premio Pulitzer. Sin embargo, más tarde se descubrió que Jimmy era una ficción de la periodista, quien tuvo que devolver el galardón y perdió la que era una promisoria carrera.

En esta columna sobre Janet Cooke, García Márquez afirma que si un escritor dice que vio volar a un rebaño de elefantes nadie le creerá, pero "no faltará quien se lo crea si apela al recurso periodístico de la precisión y dice que los elefantes que volaban eran 326" (1991a, p. 97). Este detalle es fundamental porque lo que está diciendo es que una hipérbole, o incluso una falsedad, puede resultar verosímil si se le agrega un detalle numérico específico. Es decir, el texto podría ser creído si además del relato también "cuenta”, no en el sentido de narrar, sino en la acepción de "enumerar”, otorgándole de esta manera a las cifras un peso irrefutable. Esto es lo que precisamente hace García Márquez desde sus textos tempranos en la prensa, construir hipérboles en los que hay una acumulación y un hacinamiento de datos fácticos, por un lado, para atraer la atención de su público lector y, por otro, para dar una dosis de verosimilitud a sus historias, ya que un número específico es un dato contundente.

Hay que resaltar, además, que el título de esta columna es “¿Quién cree a Janet Cooke?”, donde el verbo es “creer". De manera que el escritor al escoger el título -y de esta manera jerarquizar la temática de su columnase enfoca en lo que es creíble (o en lo que no lo es) y no necesariamente en si lo que se cuenta es verdadero o falso. Aunque es cierto que dentro del texto afirma que un dato falso "desvirtúa" a los otros que son verídicos, está usando el verbo "desvirtuar", que quiere decir "quitar a algo la virtud" o "alterar la verdadera naturaleza de algo" (Real Academia Española, 2020) y no está empleando otros verbos que pudieran resultar más directos, como "cancelar" o "negar", por ejemplo. Es llamativo que también diga que "hay que apegarse a la verdad, aunque nadie la crea”. ¿Por qué alguien no va a creer la verdad si se está construyendo discursivamente una representación de ella? Tal vez está sugiriendo entonces que la verdad de un texto podría residir en si es narrado de manera creíble o no. Es decir, este comentario encierra toda una problemática ética de fidelidad y de “apego". Entonces, ¿cómo juzgaría García Márquez sus propias licencias fácticas de sus textos tempranos de prensa?

La crítica Claudia Claridge se pregunta qué pasa cuando hay una tensión entre la "verdad factual” y la "verdad emocional", por ejemplo, si cuando un hablante enuncia una exageración y sinceramente cree que es verdad. ¿Se puede considerar que aquello es todavía una hipérbole? (2011, p. 19). Es decir, si cuando García Márquez incurrió en licencias fácticas en sus Jirafas, pero él creía vehemente que eran verdad (o quería creerlo), ¿eran todavía hipérboles? Si tomamos en cuenta solo la intención del hablante (en este caso, el escritor) entonces esto es problemático. Pero si tomamos en cuenta también los hechos y la percepción del público podríamos concluir que sí son hipérboles. A pesar de que García Márquez creyera firmemente que aquello que escribía era verdad, añadió algo de más, abriendo una brecha entre lo que decía y la realidad empírica. Y en algunos casos, ese algo de más añadido podría tomar la forma de una mentira. En todo caso, aquí el público lector juega un papel fundamental, al abrazar o no con su credulidad las exageraciones. 


\section{EL POETA FICCIONAL}

En la ciudad de Cartagena el joven García Márquez comenzó a trabajar para el diario El Universal y es allí donde está la génesis de su diarismo mágico. El propio escritor documentó cómo una de las primeras cosas que hizo en sus inicios periodísticos en El Universal fue pedirle a su editor, Clemente Manuel Zabala, que le enseñara a escribir reportajes (García Márquez, 2002, p. 410). Zabala, con su famoso lápiz rojo, corrigió los primeros textos periodísticos de García Márquez y lo influenció en el uso de artificios estilísticos como los comienzos y los remates impactantes, las frases ingeniosas, los adjetivos precisos, una constante actitud de sorpresa y las alusiones literarias (García Usta, 2007, p. 235). Es decir, el editor jugó un papel doble, no solamente de "censor" sino también de "profesor".

En esta primera etapa, el joven García Márquez escribió una columna titulada Punto y aparte, en la que no solo se aprecia su uso de la hipérbole sino también la introducción de personajes ficcionales. Por ejemplo, en su columna del 29 de junio de 1948 el joven escritor cuenta que un importante poeta de Colombia, llamado César Guerra Valdés, había visitado la sala de redacción de El Universal. En este texto, García Márquez elogia al poeta y explica que este "autor de cinco libros fundamentales" es "uno de los grandes revolucionarios estéticos” de América Latina (1991b, p. 79). La nota resalta la calidez de la escritura de Guerra Valdés y menciona que, aunque pasa inadvertido en el ambiente local, este escritor está provocando una renovación en la literatura latinoamericana. En un giro para capturar la atención de los lectores, con un detalle sobre las apariencias, García Márquez expresa su sorpresa ya que dice que, por la fuerza de su escritura, imaginaba a Guerra Valdés como un hombre alto y de voz potente, pero tras verlo en su visita al diario se ha topado con lo contrario. Es decir, sugiere una disonancia, una brecha entre las sensaciones que transmite la literatura y la realidad, que percibe cuando se encuentra cara a cara con el autor. Esta es una de las características mencionadas de la hipérbole, la brecha entre lo lingüístico y lo extralingüístico. Es decir, César Guerra Valdés es una corporeización de la hipérbole.

Como se ha documentado, el poeta César Guerra Valdés era un personaje ficticio, ya que nunca existió (García Márquez, 1991b, p. 30). Es decir, el poeta descrito en la columna Punto y aparte era una invención. García Márquez confesó años más tarde que ese poeta apócrifo nació de la imaginación de uno de sus compañeros en la redacción, el escritor Héctor Rojas Herazo (1991b, p. 37). ¿Por qué y para qué García Márquez describe a sus lectores a un poeta imaginario como si fuera verdadero? ¿Cuál es la función de ese personaje-poeta ficcional? Tal vez se pueda esbozar una respuesta a partir de la visión que en ese momento García Márquez tenía del canon literario colombiano, particularmente de los primeros dos tercios del siglo XX. En una entrevista con el crítico Luis Harss, García Márquez aseguró que la literatura de su país era un "inventario de muertos" debido al estancamiento y al conservadurismo de sus escritores, la mayoría académicos y gramáticos (1966, p. 381). De manera que, en contraste con la frialdad de esa literatura, García Márquez posiblemente ansiaba a un escritor cálido, potente y renovador. Pero como creía que no existía, decidió apoyar su invención. Esa aparición de César Guerra Valdés en las páginas de El Universal, en complicidad con otros periodistas y editores, probablemente sea producto de una disonancia entre la literatura que él quería sentir y la realidad que apreciaba en el ambiente literario colombiano.

Los críticos Jacques Gilard (1991b, p. 37) y Pedro Sorela (1988, p. 29) coinciden en que probablemente Guerra Valdés habría sido inspirado en el poeta chileno Pablo Neruda. Sin embargo, eso no es incompatible con el interés de García Márquez por contar con un escritor colombiano que trascendiera más allá de su país y tuviera una apelación internacional. De hecho, la crítica María Helena Rueda explica cómo en su etapa de periodista para la agencia Prensa Latina, García Márquez dejó constancia de cómo a los escritores colombianos de entonces les faltaba un valor "universal” (2017, p. 174). Para García Márquez, la razón de que los literatos colombianos no trascendieran las fronteras nacionales radicaba en que hasta el momento no habían sabido representar el drama de su propio país. Rueda (2017) sostiene que uno podría especular 
que García Márquez estaba dando pistas de cómo su propio proyecto literario intentaba capturar el drama colombiano de manera que pudiera ser leído en cualquier parte del mundo.

En sus años como periodista en el Caribe, uno de los aspectos que García Márquez trabaja es la escritura de títulos hiperbólicos y sensacionalistas. Esta técnica de generar un choque de sensaciones a través de la titulación, pronto la trasladó también a sus cuentos y novelas. Para el crítico Gerald Martin, el primer cuento del escritor que "ya suena" a título garciamarquiano es uno que escribe en esta época de los diarios, "Nabo, el negro que hizo esperar a los ángeles" (2009, p. 186). En el ambiente de colmena productiva que era la redacción de El Universal, García Márquez mantuvo un activo intercambio de ideas estilísticas con sus colegas periodistas, entre ellos Gustavo Ibarra Merlano y Ramiro y Oscar de la Espriella, con quienes comentaba los manuscritos de dos novelas en las que trabajaba en ese período, La hojarasca, que publicó pocos años después y La casa, que es el embrión de lo que posteriormente se convirtió en Cien años de soledad ${ }^{4}$.

Es importante reiterar que este proceso creativo del uso de la hipérbole y la ficcionalización es un fenómeno de doble vía, de ida y vuelta, donde se dan intercambios, traslapes e hibridaciones, tanto en las referencias mutuas entre ficción y no ficción como en sus contenidos. Por ejemplo, en su novela La mala hora (1962), una de las imágenes principales es la de los pasquines u hojas periodísticas difamatorias que circulan en un pueblo donde se revelan sórdidos secretos (García Márquez, 1966, p. 74). En este zigzagueo de doble vía, algunas de las asignaciones y tareas de su época periodística se convirtieron en borradores temáticos para novelas que escribió años más tarde. Por ejemplo, el propio García Márquez narra cómo el 26 de octubre de 1949, su editor Clemente Manuel Zabala se dio cuenta de que en la ciudad de Cartagena estaban vaciando las criptas funerarias de un antiguo convento de monjas clarisas. La limpieza de aquellas criptas era parte de un proyecto empresarial que iba a convertir al antiguo convento en un hotel de lujo. Al enviar a García Márquez para que recopilara la información y escribiera la noticia, Zabala le dijo: "Date una vuelta por allá a ver qué se te ocurre" (1994a, p. 9). Zabala usó el verbo "ocurrir", que evoca una idea que se viene a la mente de forma repentina e inesperada, y que está emparentada con la palabra "ocurrencia”, que tiene que ver con los pensamientos imaginativos (Real Academia Española, 2019a). Es decir, que para producir el discurso noticioso el editor le pide a su periodista ser creativo y usar su imaginación.

En el convento, García Márquez atestiguó cómo varios trabajadores excavaban y desenterraban fosas antiguas de muertos ilustres. Junto al altar, en una de las criptas, yacía la noticia que buscaba: allí estaban los restos óseos de quien había sido una niña llamada Sierva María de Todos los Ángeles, cuya cabellera extendida en el suelo medía veintidós metros y once centímetros, según la versión de García Márquez. Es importante cómo en este dato hiperbólico hay una exageración del detalle y, al mismo tiempo, una precisión en la exageración: una cifra ("veintidós metros y once centímetros"), un elemento que "cuenta" numéricamente y le da una dosis de racionalidad a su narración. Según el escritor, uno de los trabajadores le explicó que el cabello humano podía crecer después de la muerte hasta un centímetro por mes (1994a, p. 11). Esta declaración, que el periodista supuestamente atendió sin cotejarla con fuentes científicas, le sirvió para escribir la noticia del día y la archivó, junto con el resto de datos, para 45 años después retomarlos y desarrollarlos en la novela Del amor y otros demonios.

En este fenómeno de doble vía, el propio García Márquez afirmó que, por un lado, su obra creativa le dio "valor literario" a sus "escritos periodísticos", mientras que por otro, obras como El coronel no tiene quién le escriba (1961), La mala hora (1962) y Los funerales de la mamá grande (1962) tienen en común el hecho de que en ellas hizo "literatura periodística" (Sorela, 1988, p. 8). El crítico Gene Bell-Villada considera que un texto como Noticia de un secuestro tiene las características de un thriller de suspenso, sin embargo, es una historia verdadera (2010, p. 270). En la misma línea, el crítico Robert Sims asegura que la novela Crónica de una muerte anunciada (1981) y la autobiografía Vivir para contarla (2002) forman un díptico interconectado por su uso poco convencional del narrador en primera persona, por la fusión de sus componentes reales y ficcionales y por el desplazamiento de la cronología y de la historia oficial para dar paso a la "historia 
sentida" ("felt history") (2016, p. 198). Otros ejemplos de intercambios de doble vía entre ficción y no ficción también están presentes en obras como Relato de un náufrago (1970) y El general en su laberinto (1989) 5

\section{La marquesa de García Márquez}

En sus comienzos literarios, García Márquez escribe cotidianamente textos en periódicos, que por su naturaleza de publicación diaria pueden estar destinados a un rápido olvido. Una de las características del periodismo es su fugacidad y, en la tradición literaria latinoamericana, son ampliamente conocidas las quejas de muchos escritores que trabajaron en diarios y revistas, como el cubano Julián del Casal, quien sostenía que, por su labor periodística, la recompensa que obtenía era "aplausos efímeros" (1963, p. 287). El empleo de la hipérbole y de personajes ficcionales en los diarios en los que escribe García Márquez, con su efecto de exceso y desbordamiento, es parte de esa búsqueda de un estilo propio, pero acaso, adicionalmente, tal vez sea un esfuerzo también por extender la durabilidad de los textos en la memoria de los lectores.

En su etapa en el Caribe, García Márquez fue miembro activo del llamado Grupo de Barranquilla, una tertulia de periodistas, escritores y bohemios interesados por la literatura, el cine, la política y la actualidad. El núcleo del grupo estaba integrado por Germán Vargas, Alfonso Fuenmayor, Álvaro Cepeda Samudio y el propio García Márquez, quienes tenían como guía literario y estético a un intelectual catalán llamado Ramón Vinyes, fundador de una librería y de la revista de vanguardia Voces $^{6}$. Con este grupo, el joven escritor se sumergió en la lectura de autores como William Faulkner, John Dos Passos, Ernest Hemingway y Virginia Woolf (Vargas, 1985, p. 151). Es precisamente en la lectura de Woolf que García Márquez encuentra el nombre de Septimus, que decide usar como pseudónimo para firmar sus Jirafas ${ }^{7}$.

En la columna La Jirafa se nota cómo hay una coincidencia con los temas que predominan en la producción novelística de García Márquez, como el hecho increíble o fantástico, la tecnología, la decadencia del mundo moderno, la muerte, la locura y el escepticismo ante los métodos racionales de interpretación (Williams, 1985, p. 124). En estos textos el incipiente escritor sugiere -sutil o abiertamente- sus posturas políticas, estéticas y sociales, y las galvaniza con un tipo de humor muy particular, que en el Caribe colombiano llega a ser conocido como el "mamagallismo" 8 , cuya particularidad es el "gusto por la tomadura de pelo" (Martin, 2009, p. 24) y que tiene un énfasis en las sensaciones, por su deseo por rechazar la solemnidad y, a la vez, causar escozor.

En abril de 1950, el joven García Márquez publicó una Jirafa titulada “Un cuento de misterio” en la que narra la vida de una extravagante marquesa alemana y su esposo Boris, un millonario que le envía regalos excéntricos desde el extranjero y contrata a un sicario para matarla el día de su cumpleaños. Según contaba la columna, la marquesa era una políglota que hablaba, entre otros, alemán, ruso, griego e inglés (la columna estaba escrita en español), tenía 32 canarios y siempre que le daba alpiste a su canario número 13 alguien llegaba a asesinarla. De acuerdo con la columna, la marquesa ya había muerto varias veces, un detalle que revelaba la imposibilidad de que el texto se refiriera a una persona real. En el relato, la marquesa se muestra emocionada y agradecida por el gesto de su esposo, quien al contratar al asesino a sueldo no se había olvidado de su cumpleaños. Es decir, en este texto, en un giro de los valores convencionales, la muerte violenta no se considera un crimen sino un regalo. El sicario, cuando se presenta para cumplir con su trabajo, trata de hacer breve la conversación con la marquesa pues, según explica, ese día tenía que asesinar también a siete condesas, ocho duquesas y una cenicienta. Al final del texto, la marquesa se tiende sobre un diván y cierra los ojos para que el sicario la asesine.

En esta columna, el desbordamiento incluye una exageración en su cantidad de detalles (por ejemplo, las nacionalidades, los idiomas, las muertes y las situaciones absurdas) y también contiene una precisión en las exageraciones (el número exacto de canarios, la muerte aparece con el canario número 13, los asesinatos pendientes del sicario). Además, esta columna, titulada con la palabra "cuento", no solamente se limita a 
su dimensión de "relatar" y "referir" sino que, mostrando la polisemia de este léxico, también "numera" y "computa" una serie de exageraciones, en una presencia del conteo o enumeración que es característica de la estética hiperbólica de García Márquez. Como lo explica Nelson Freddy Padilla, un periodista que trabajó con el escritor, en su periodismo hay una obsesión por la enumeración de detalles (N. F. Padilla, comunicación personal, 1 de febrero de 2011). En el caso de la historia de la marquesa, el rebosamiento sobrepasa a la columna de aquel día, ya que el periodista decide continuar escribiendo al menos una vez por semana sobre la vida de la noble alemana y su esposo Boris. Es así como entre el 5 de abril y el 7 de junio de 1950, García Márquez dedica sus Jirafas de los miércoles -y, excepcionalmente, también las de otros días- a escribir una saga de la marquesa, que, evidentemente, como el público lector infiere, es un personaje producto de su imaginación?.

Mientras que en sus otras Jirafas del resto de la semana, el periodista continúa elaborando comentarios y los llamados "refritos" miércoles se dedica exclusivamente a describir la vida de la marquesa, incluyendo en su narración elementos sobrenaturales, como por ejemplo, un elefante blanco que se desmaya, una silla mágica que acelera la vejez en quien se sienta en ella y fantasmas que le piden a la marquesa vivir en su casa. Sin embargo, a pesar de que estos elementos van evidentemente más allá de la realidad empírica, en una de sus columnas García Márquez decide incluir una aclaración explícita, al apuntar que había olvidado decirles a sus lectores de El Heraldo que los hechos que narraba sobre la marquesa no eran reales.

Más adelante, en esa misma columna, relata el encuentro con una mujer que un día lo llegó a buscar a la sala de redacción:

«Quién es usted?». Y la dama respondió, estirada y digna: «iSoy la marquesa!»: Encendí un cigarrillo. Después de la primera chupada fuerte y bien meditada, empecé a hablar: «Debo lamentar, señora, decirle que está usted evidentemente equivocada. Los personajes de mis notas -inclusive el elefante blanco- son todos imaginarios.» La dama se puso encarnada. «¿Imaginaria, yo? -dijo, con los ojos amenazantes-: ¡es el peor insulto que se me haya hecho jamás!» «No me refiero a usted, señora -le respondí-; me refiero a la marquesa de los miércoles». «Es lo mismo -dijo ella-. Yo soy la marquesa y no estoy dispuesta a aceptar que usted me considere como una mujer imaginaria.» (García Márquez, 1991b, p. 192).

Este intercambio continúa con una serie de afirmaciones de la marquesa, quien reitera que ella es verdadera y, como prueba, enumera y comenta una exageración de detalles y una precisión en las exageraciones de su vida personal. La exactitud de los detalles termina por convencer al columnista, quien no tiene más remedio que asegurar que la marquesa es real. Al despedirse, Septimus (García Márquez) se ofrece acompañarla a la puerta, pero ella le contesta que no es necesario, ya que es alérgica a las escaleras. Y, según el texto, la reunión concluye cuando la marquesa se arroja por la ventana desde un segundo piso.

Este pasaje es muy útil para analizar cuál es la relación que en estos textos juega la hipérbole con el apego a la verdad, la verosimilitud, la mentira y la ética. La prensa posee durante el siglo XX un poder de autoridad documental como detentor de verdad(es). El crítico Roberto González Echevarría ha explicado cómo en América Latina el género de la novela en determinados períodos históricos asumió las formas de documentos que, ante la sociedad, tenían el poder de desplegar la verdad. Es decir, la novela imitó a otros tipos de discursos para mostrar su convencionalidad, su sujeción a reglas textuales de género, similares a aquellas que gobiernan a la literatura, las cuales, a su vez, reflejan las del lenguaje (1984, p. 360). González Echeverría sostiene que, por la convencionalidad de detentar la verdad, durante el siglo XVI la novela en América Latina imitó a los discursos legales; en el siglo XIX, al lenguaje de la ciencia; y en el siglo XX, a los discursos antropológicos. Sin embargo, González Echevarría pasa por alto la importancia que cobra la prensa en el siglo XX como discurso documental impreso depositario de verdad(es). Los discursos periodísticos se convierten en una forma de consulta diaria para los lectores, quienes -dependiendo de sus inclinaciones ideológicas- escogen aquellos periódicos con los que se sienten afines y depositan en ellos una alta dosis de credulidad como fuente(s) referencial(es). Es por eso que cuando García Márquez aclara que la historia de la marquesa es producto de su imaginación está reconociendo que su saga puede generar una duda en los lectores del diario al leer sus 
exageraciones e invenciones dentro de un producto escriturario del que -idealmente- se espera el apego a una verdad referencial empírica apoyada en datos verificables.

Otro aspecto importante de este pasaje es el momento en que García Márquez describe su reunión con la marquesa. Aquí hace una operación de auto-transformación, ya que crea una representación para sí mismo como personaje dentro de una escena imaginada, en la que conversa con un personaje imaginario. Es así como García Márquez está haciendo una operación de ficcionalización dentro de su columna; es decir, desata las amarras que mantienen el apego a una realidad verificable y construye una metaficción. Es la especie de "no referencialidad” en el texto que Catherine Gallagher describe como una gran referencialidad (2006, p. 342). Sin embargo, este proceso de ficcionalización, en el que se crea una "no referencialidad" dentro de la Jirafa, es algo característico de la novela, no necesariamente de los periódicos. De ahí que en la escena en la que el periodista le dice a la marquesa que los personajes de sus notas "son todos imaginarios" está admitiendo que su columna subvierte las convenciones periodísticas. Paradójicamente, también está acatando estas mismas convenciones. $\mathrm{Al}$ admitir la fabricación de personajes, algo convencionalmente considerado en contra de la ética periodística, García Márquez está reconociendo su intento por novelar dentro del periódico. Al decir que sus personajes "son todos imaginarios" está él mismo desenmascarando su engaño; en un principio, irrespeta y subvierte, pero después, acata las convenciones de su periódico. Esto puede catalogarse como un "engaño honesto" ("honest deception"), un término utilizado por Leech para describir a ciertas hipérboles (Claridge, 2011, p. 18). En todo caso, está incurriendo en otra exageración, ya que no todos los personajes a los que se refiere su columna son imaginarios.

En la escena del encuentro, al ser llamada "imaginaria", la marquesa asegura que ese es el "peor insulto" que le hayan dicho. Esta afirmación pone de relieve una característica propia de la relación entre la prensa y sus lectores, cimentada a partir de la premisa de que aquello impreso en sus páginas es un tipo de verdad y, por eso, cuando se duda de la veracidad impresa del diario se considera una ofensa. Pero, a la vez, muestra las costuras de la ficción: en la novela, la verdad deja de ser una construcción relacionada directamente con la precisión histórica. Como lo explica Gallagher, este es un salto epistemológico, ya que en la novela se pasa a una comprensión más amplia de la verdad, que la concibe como una simulación mimética y, además, acepta a la verosimilitud como una forma más de verdad (2006, p. 341). Es decir, la marquesa no es un personaje verdadero desde la perspectiva de los discursos periodísticos, ya que no corresponde con una persona real, pero sí lo puede ser como personaje dentro de la no referencialidad de la ficción. Este pasaje también muestra las costuras del periodismo, pues originalmente era una explicación del periodista a los lectores a quienes les quería comunicar que su columna era una ficción, pero al final su mismo texto de aclaración termina siendo una ficción más.

Un aspecto importante a considerar es, entonces, precisamente, la verosimilitud, es decir, la apariencia de lo verdadero y el ámbito de lo creíble. Como lo explica la crítica Susana Rotker, la verosimilitud no debe confundirse con la verdad, ni tampoco de la verosimilitud se pueden derivar conclusiones tajantes como que la ficción pertenece exclusivamente al campo literario y lo verdadero al periodismo (1992, p. 110). ¿Resulta el personaje de la marquesa y las situaciones que se narran sobre ella en algún grado verosímiles? ¿Cómo reacciona el público lector de La Jirafa? ¿Y cómo es recibida la articulación que se hace del personaje de la marquesa, por ejemplo, cuando el columnista reconoce que todos sus personajes son imaginarios? Es difícil saber con certeza los distintos matices de la recepción de esta saga, sin embargo, se puede llegar a tener alguna noción por el propio testimonio escrito de García Márquez. En las Jirafas tituladas "Carta abierta a la marquesa" e "Inexplicable ubicuidad de Boris", el joven escritor cuenta cómo algunos lectores han comenzado a enviarle cartas con sus opiniones sobre el personaje de los miércoles y en las calles de Barranquilla otras personas lo abordan directamente sobre el tema, ya que saben que él es Septimus, el autor de la columna. El periodista escritor asegura que ha recibido opiniones a favor y en contra: hay quienes lo apoyan, pero también hay quienes le piden que deje de escribir sobre la marquesa. Este contacto personal a raíz de un personaje imaginario lo lleva a afirmar, en otra Jirafa, que la marquesa ha logrado algo que él creía improbable: la 
correspondencia con el público (García Márquez, 1991b, p. 244). Es decir, su texto ha logrado una inesperada interactividad con quienes compran y leen el diario.

García Márquez explica cómo incluso le han llegado cartas a la redacción con sugerencias para continuar la saga, con comentarios de lectores que dicen conocer detalles íntimos de la marquesa y con fotografías supuestamente pertenecientes al esposo de la noble alemana. Según dice, algunas lectoras han llamado por teléfono al diario y han dejado recados de parte de la marquesa. Desde luego, esta es la versión relatada en sus Jirafas por García Márquez y no hay evidencia extra-textual de lo que cuenta, por eso existe la posibilidad de que esto también forme parte de sus invenciones. En todo caso, el periodista escritor cuenta que se ha encontrado en las calles de la ciudad con personas que le han afirmado que ellos son Boris. Es decir, la reacción del público lector pudo haber provocado una ficcionalización extra-textual y colectiva que traspasó los límites de la columna y del autor individual. Pero hay muchas otras posibilidades, entre ellas que esta sea una función textual, un juego infinito, de muñecas rusas o cajas chinas que proceda de avalar la referencialidad. En todo caso, el texto logra lo que Maurice Blanchot sostiene al afirmar que es el público lector quien hace la obra: "Leyéndola, la crea" (1991, p. 19). De esta manera, García Márquez alcanza una "correspondencia” no solo en la acepción de la comunicación, escrita y oral que establece con los lectores, sino también porque con su personaje provoca estímulos, desencadena una serie de sensaciones que lleva a parte de su público querer sumarse y ser parte de su invención del periódico.

Esta reacción también se puede explicar a partir de lo que Gallagher teoriza sobre la ficción en la novela, cuando explica que en el proceso de ficcionalización existe "a disposition of ironic credulity enabled by optimistic incredulity” (2006, p. 346). Es decir, los lectores pueden no creer en una verdad literal de la representación de la marquesa, pero pueden creer en una verdad que funciona dentro de la ficción y le dan crédito suficiente como para sumarse al juego. Este tipo de credulidad es una condición de la ficcionalidad y genera opiniones, no acerca de la veracidad del texto, sino más bien sobre su verosimilitud, sobre su plausibilidad. Por eso es que una parte de los lectores cree, dentro del mundo de ficción creado en La Jirafa, que la marquesa es un personaje posible, e incluso otros lectores quieren creer que ellos mismos son la marquesa o Boris.

García Márquez confiesa en una de sus Jirafas que crear el personaje de la marquesa ha sido una "válvula de escape" para su creatividad, algo que él reconoce como una "conducta literaria" dentro de las páginas del periódico (1991b, p. 244). Es decir, esta es una aclaración, pero a la vez una declaración de intenciones: ante su creatividad desbordante, el joven García Márquez reta los moldes del periodismo que lo aprisionan. La transgresión escrituraria, en este caso, consiste en ir más allá de los límites del periodismo. Lo que no dice el joven escritor es que la marquesa es posiblemente una proyección especular de sí mismo. No solamente sus nombres guardan una gran semejanza (marquesa/García Márquez), sino que el personaje literario de su columna periodística está alcanzando ese objetivo al que aspira el escritor en su proceso de experimentación: ser leído y generar sensaciones que provoquen reacciones.

En sus distintas Jirafas sobre la marquesa, García Márquez hace guiños a sus lectores y va dejando desperdigadas pistas, en las que sugiriere, directa o indirectamente, esta contienda personal/literaria entre su búsqueda por un estilo autoral propio y los límites que le impone periodismo. Por ejemplo, en otra de sus Jirafas, titulada "El hindú y el desconcierto de la marquesa", el joven escritor alude al tema de las apariencias y el engaño. En esta columna García Márquez narra cómo un día llega a la casa de la marquesa un humilde hombrecillo hindú cubierto con una túnica y cargando un cesto en sus brazos. La marquesa, acostumbrada a recibir regalos que Boris le envía desde sus viajes, piensa que el cesto contiene un presente de su marido. Sin embargo, el hombrecillo le aclara que no hay tal regalo en el cesto porque el regalo es él mismo y agrega que él es un "encantador de serpientes" (García Márquez, 1991b, p. 237). A continuación el hindú pasa a la sala y se sienta sobre una alfombra. Seguidamente, destapa el cesto y comienza a tocar una flauta. Al son de la música comienza a asomarse lo que, en principio, parece una serpiente. Pero el animal continúa saliendo y resulta tener un largo cuello amarillo y manchas negras que termina por salir con sus largas patas: es una 
jirafa. Ante esto, la marquesa protesta diciendo que el regalo de Boris le resulta un espectáculo "aburrido". El texto concluye con el siguiente diálogo:

-Usted no encanta a nadie, dijo la marquesa.

-Encanto serpientes, dijo el hindú. Pero aquí ha habido un error. Esto no es una serpiente: alguien para burlarse de mí, metió una jirafa dentro del cestillo (García Márquez, 1991b, p. 237).

En esta historia hay dos desencuentros debido a las representaciones. En primer lugar, la marquesa piensa que dentro del cesto está su regalo. Sin embargo, para su sorpresa, el regalo no es el objeto que observa sino el sujeto que lo carga y que ella pensaba que era apenas un mensajero. El segundo desencuentro se da cuando del cesto del encantador no sale, como se esperaba, una serpiente, sino que lo que emerge es una jirafa, en clara alusión a su propia columna. En ambos casos, estos dislocamientos provocan el desconcierto de la marquesa, ya que las convenciones sociales la llevan a tener ciertas expectativas, pero obtiene algo diferente y esto la deja con una sensación de desencanto. García Márquez escribe su columna en un periódico que sigue un modelo de periodismo comercial. Según este modelo, los lectores esperan que el discurso esté escrito de acuerdo con ciertos valores, entre ellos, la fidelidad a una(s) verdad(es) verificable(s). Sin embargo, García Márquez ofrece en su columna una serie de exageraciones y situaciones con personajes exagerados o imaginarios en distinto grado que dislocan las expectativas.

Si bien una parte de sus lectores se ha sumado a participar de la ficción de la marquesa, otras personas, como él mismo lo reconoce, le han expresado que su columna se ha convertido en "un desorden" (García Márquez, 1991b, p. 244). Por eso, García Márquez se ve a sí mismo como un “encantador de serpientes”, que crea una expectativa de cierto tipo de representaciones, pero termina ofreciendo algo diferente. Es llamativo el uso de la imagen de la serpiente, un animal que puede ser venenoso y que en la cultura Occidental evoca al engaño, es decir, a la mentira como apariencia de verdad. Pero también es un animal que evoca a la seducción, en este caso, la seducción por la lectura y la compra del diario. Y precisamente ese es uno de los objetivos del sensacionalismo, seducir al público para que lea. Pero para leer, el prerrequisito es comprar el diario. El regalo que García Márquez ofrece no es siempre información. El regalo es él mismo, el joven que experimenta y busca articular una estética literaria propia, el encantador de serpientes que pide ser aceptado en su proceso de ficcionalización, porque sabe que las constantes dislocaciones pueden causar "desorden", es decir, desconcierto, hastío o, como lo dice la propia marquesa, aburrimiento. El hindú del relato (García Márquez) posa ante los lectores como una supuesta víctima al afirmar que es el blanco de un engaño ya que, según dice, alguien ha colocado una jirafa en el cesto (el periódico) para burlarse de él. Pero en realidad, es García Márquez quien hace el artificio de hiperbolizar e introducir historias ficcionales en su Jirafa.

En este juego textual, el joven García Márquez cuenta, por un lado, con la complicidad de sus editores, quienes le permiten escribir sobre un personaje imaginario, y por otro, también con la complicidad de una parte de los lectores, aquellos que asumen la verosimilitud de la marquesa dentro de la ficción. Esta, posiblemente, sea una de las causas por las que el joven escritor, después de dos meses, dejó de escribir sobre este personaje, ya que la marquesa comenzó a ser aceptada como parte de un mundo ficcional, pero no como parte del mundo real. Y continuar escribiendo sistemáticamente sobre un personaje imaginario en un periódico, donde se espera leer sobre personas y situaciones reales, podría generar fastidio, tanto de los lectores como del propio autor, como lo reconoció el mismo escritor. La saga de la marquesa es un caso llamativo entre los numerosos ejemplos de experimentación que el joven García Márquez emprendió en esta época desde los periódicos. Incluso en sus columnas más informativas ya se nota una tendencia a la adjetivación hiperbólica.

\section{El PERIódico Comprimido}

Ducrot y Todorov definen a la hipérbole como una "aumentación cuantitativa de una de las propiedades" de un objeto o un estado (1974, p. 319). Eso es precisamente lo que hace García Márquez en otro de sus 
proyectos periodísticos, un diario con un nombre y una aspiración hiperbólica, que él mismo dirigió y escribió brevemente. El 18 de septiembre de 1951 el joven García Márquez lanzó en la ciudad de Cartagena un nuevo periódico de ocho páginas al que llamó Comprimido. Ante el lanzamiento de un nuevo medio de información en la ciudad, el diario El Universal, en el cual García Márquez había trabajado previamente, informó del nuevo proyecto y lo describió como un periódico que publicaba noticias "con la brevedad y la elocuencia de una píldora" (Flores Sierra, 1989, p. 14). En el editorial de su primer número, García Márquez escribió: "Comprimido no es el periódico más pequeño del mundo, pero aspira a serlo con la misma laboriosa tenacidad con que otros aspiran a ser los más grandes" (1991b, p. 22). La hipérbole garciamarquiana, en este caso, lo que hace es intensificar las propiedades de la brevedad y esto implica disminuir algo que originalmente ya es corto. Es decir, la hipérbole funciona como un resorte no solo para expandir sino también para comprimir exponencialmente las propiedades de un objeto, una persona o una circunstancia.

La comparación del diario Comprimido con una "píldora" y la afirmación de que no es el periódico más pequeño, aunque sí "aspira a serlo", constituyen un reconocimiento del valor que tiene la brevedad en los discursos periodísticos que siguen un modelo comercial. El crítico Julio Ramos ha documentado cómo desde finales del siglo XIX los periódicos latinoamericanos pasaron por una transición al dejar de ser brazos escriturarios de partidos políticos para convertirse en empresas comerciales que, en una voluntad de autonomía y modernización, comenzaron a proclamar su "objetividad" (1989, p. 97).

El 23 de septiembre de 1951, apenas unos pocos días después de su primer número, el diario Comprimido anunció su prematuro final:

Comprimido dejará de circular desde hoy, aunque sólo de manera aparente. En realidad consideramos como un triunfo nuestro -y así lo reclamamos- la circunstancia de haber sostenido durante seis días, sin una sola pérdida, una publicación diaria que según todos los cálculos cuesta un noventa y nueve por ciento más de lo que produce.

Ante tan halagadoras perspectivas, no hemos encontrado un recurso más decoroso que el de comprimir este periódico hasta el límite de la invisibilidad. En lo sucesivo, Comprimido seguirá circulando en su formato ideal que ciertamente merecen muchos periódicos. Desde este mismo instante, éste empieza a ser -para honra y prez de nuestros ciudadanos-el primer periódico metafísico del mundo (García Márquez, 1991b, p. 23).

En este editorial, la hipérbole tiene que ver con el verbo "comprimir", que evoca directamente el nombre del diario. García Márquez admite el fracaso financiero de su proyecto, pero lo hace con un dejo de humor e ironía, apelando al mamagallismo caribeño, al afirmar hiperbólicamente que el cierre de Comprimido es un "triunfo", lo cual evidentemente es una exageración cuando no una mentira. Seguidamente, para controlar el desbordamiento de su hipérbole, así como para impregnarle verosimilitud, incluye un detalle de precisión (que cuenta, en el sentido de narrar, y a la vez, de enumerar) al afirmar que el diario cuesta "un noventa y nueve por ciento más de lo que produce". El joven estira la hipérbole superlativamente al afirmar que en adelante va a comprimir la materialidad de su diario hasta hacerlo impalpable. El público lector sabe que es imposible que un periódico continúe circulando de manera invisible. El absurdo y la ironía de esta declaración, además, le sirve al mismo tiempo para lanzar una crítica por la (baja) calidad de otros periódicos, que el joven García Márquez considera que ni siquiera deberían de existir. La hipérbole es aquí un artificio no solo para informar (del cierre temprano de su proyecto), sino también para opinar y criticar (la calidad de otros periódicos), así como para entretener, con ese estilo que a la vez que captura la atención, produce una tomadura de pelo.

\section{CONCLUSión}

En la adquisición de conocimiento es fundamental el rol de los sentidos y en la obra de García Márquez la apelación a los sentidos es central. El propio autor lo admitió al confesar que cuando escribía lo que pretendía era llevar al lector "de la mano" para que viera y sintiera la historia que se le estaba narrando, de manera que no se perdiera ni quedara ningún punto oscuro (Harss, 1966, p. 418). En los textos de García Márquez, ese afán por hacer que el lector "vea" y "sienta" se traduce en una abundancia, en una intensificación que 
lleva al desbordamiento, es decir, una sensación de ir más allá de la plenitud. Pero si el texto no se puede ver, como en el caso de la columna borrosa del trompetista, se genera entonces un problema en la transmisión de conocimiento. El columnista no puede comunicar sus impresiones, ni tampoco generar impresiones en sus lectores porque hay un problema de impresión en los textos. Es decir, la inconclusión de las acciones de "imprimir" e "impresionar" producen una contrariedad. Estos dos verbos provienen del mismo origen latino, in que significa "en, sobre, con" (Moliner, 2007, p. 1613) y premere, que tiene que ver con la acción de "estampar", "hacer presión" o "marcar una huella" y que está emparentado con palabras como "oprimir", "reprimir" y "suprimir", así como con el vocablo "prensa" (Corominas, 1991, p. 828). Es decir, aquí entran en juego una fuerza material que deja una marca en el papel y otra intelectual que pretende dejar una huella en los lectores.

En los ejemplos mostrados en este trabajo, García Márquez ha construido o fabricado hechos, que tienen como objetivo que sus lectores crean el mundo descrito en sus textos y queden impresionados con sus descripciones. Este proceso es lo que el filósofo Nelson Goodman ha llamado “worldmaking” o construcción de mundos: "Worlds are made by making such versions with words, numerals, pictures, sounds, or other symbols of any kind in any medium" (1978, p. 94). Lo que Goodman sostiene es que no hay una versión única de la verdad sino innumerables versiones del mundo. Esto es un reto a la noción que generaliza y equipara, por un lado, a la ficción con la falsedad y, por otro, a los hechos con entidades prefijadas o pre-configuradas.

En este sentido, no es solo García Márquez quien fabrica hechos, también los periodistas, escritores y, de manera general, artistas participan de forma activa en la construcción de mundos y de verdades. Para Goodman, las artes no deben ser tomadas menos en cuenta que las ciencias en sus procesos como modos de descubrimiento y de creación de conocimiento. Los mundos que conocemos no son solamente una herencia que proviene de los científicos, biógrafos e historiadores, sino también están influenciados por los novelistas, dramaturgos y pintores. Aunque esto parece apuntar a un severo relativismo, Goodman aclara que si bien hay innumerables versiones de la verdad o versiones correctas del mundo eso no quiere decir que todo vale, que las verdades no se pueden distinguir de las falsedades (1978, p. 94).

$\mathrm{Al}$ construir estos mundos hiperbolizados en sus textos periodísticos, surge entonces la pregunta, ¿está García Márquez de alguna forma mintiendo? ¿Cuál es la línea divisoria, si es que la hay, entre la hipérbole y la mentira? La hipérbole es un término que, en sus orígenes, está relacionado con la persuasión oratoria en la retórica clásica y, más tarde, con la estilística y la literatura. Como lo explica Claridge, la hipérbole es empleada con la intención de filtrar una postura del hablante en los hechos, pero sin falsificarlos (2011, p. 18). Este aspecto problematiza la definición de hipérbole, ya que solo el hablante puede saber o hacer saber sus intenciones. Por otro lado, la palabra "mentira" proviene del étimo latino "mentiri” y es una "expresión o manifestación contraria a lo que se sabe, cree o piensa" (Real Academia Española, 2019b). El verbo "mentir" cobra sentido en las consecuencias que provoca o en las sensaciones que transmite ya que también significa una voluntad de "inducir" a otros en un error, así como "fingir" o "aparentar". Es decir, mentir es "engañar" al hacer creer a alguien de la existencia (o inexistencia) de algo que en realidad es diferente (Moliner, 2007, p. 125). Claridge sostiene que la diferencia entre la hipérbole y la mentira radica en que mentir tiene como fin distorsionar los hechos y provocar que el lector o el oyente crea en una representación errónea (2011, p. 18). Se nota entonces cómo la línea divisoria entre ambos conceptos es muy fina y puede ser intencionalmente borrosa ya que depende, precisamente, de las intenciones del hablante o, en este caso del escritor.

En todo caso, los ejemplos de García Márquez aquí analizados desafían la idea de que hay fronteras definitivas entre la ficción y la no ficción, entre el periodismo y la literatura de América Latina. Más bien, el caso de García Márquez prueba que el escritor periodista habita una zona nebulosa (porosa y, a la vez borrosa, como su Jirafa), en la que hay un rico espacio para la experimentación y la creación de mundos "desde de" y "a partir de" las salas de redacción. Como el trompetista de su columna, el joven García Márquez es el personaje que se desvía de los moldes (del periodismo) porque está en un proceso de articulación de su estética literaria propia, es decir, está en la búsqueda de la "horma de sus zapatos". 


\section{REFERENCIAS}

Abello Banfi, J. (2017). I Don't Want to Be Remembered for One Hundred Years of Solitude or for the Nobel Prize, But Rather for My Journalism. Review: Literature and Arts of the Americas, 50(2), 178-183.

Arellano, J. (2015). Magical Realism and the History of the Emotions in Latin America. Lewisburg, PA: Bucknell University Press, The Rowman \& Littlefield Publishing Group.

Bampiniōtēs, G. (2002). Lexiko tès neas Hellēnikès glōssas: Me scholia gia tē sōstē chrēsē tōn lexeōn: hermeneutiko, etymologiko, orthographiko, synōnymōn-antithetōn, kyriōn onomatōn, epistēmonikōn horōn, akrōnymiōn (2. ekd). Grecia: Kentro Lexikologias.

Bell-Villada, G. H. (2010). García Márquez: The an and his work (2 ed., rev.expanded.). Estados Unidos: University of North Carolina Press.

Blanchot, M. (1991). De Kafka a Kafka. México: Fondo de Cultura Económica.

Calvi, P. (2019). Latin American Adventures in Literary Journalism. Pensilvania: University of Pittsburgh Press.

Camayd-Freixas, E. (1998). Realismo mágico yprimitivismo: Relecturas de Carpentier, Asturias, Rulfoy García Márquez. Maryland: University Press of America.

Casal, J. del. (1963). Crónicas habaneras. Cuba: Dirección de Publicaciones, Universidad Cental de Las Villas.

Claridge, C. (2011). Hyperbole in English: A Corpus-Based Study of Exaggeration. Cambridge: Cambridge University Press.

Corominas, J. (1991). Diccionario crítico etimológico castellano e hispánico. España: Gredos.

Dorfman, A. (1991). Someone Writes to the Future. Transition, 52, 18-34.

Ducrot, O. y Todorov, T. (1974). Diccionario enciclopédico de las ciencias del lenguaje. Argentina: Siglo Veintiuno Editores.

Flores Sierra, C. (1989). García Márquez, Grupo de Barranquilla, Grupo de Cartagena: Fábula y enigma. Bogotá: Ediciones Luna Hiena.

Gallagher, C. (2006). The Rise of Fictionality. En F. Moretti (Ed.), The Novel (Vol. 1, pp. 336-363). Nueva Jersey: Princeton University Press.

García Márquez, G. (1966). La mala hora. México: Ediciones Era.

García Márquez, G. (1991a). Notas de prensa, 1980-1984. Madrid: Mondadori.

García Márquez, G. (1991b). Textos costeños (J. Gilard, Ed.). España: Mondadori

García Márquez, G. (1994a). Del amor y otros demonios. Colombia: Grupo Editorial Norma.

García Márquez, G. (1994b). Prólogo. En J. F. Fuenmayor, La muerte en la calle (pp. 11-13). Buenos Aires: Santillana.

García Márquez, G. (2002). Vivir para contarla. Madrid: Mondadori.

García Usta, J. (2007). García Márquez en Cartagena: Sus inicios literarios. Bogotá: Editorial Planeta Colombiana.

González Echevarría, R. (1984). Cien años de soledad: The Novel as Myth and Archive. MLN, 99(2), 358-380.

Goodman, N. (1978). Ways of Worldmaking. Indiana: Hackett Pub. Co.

Guillén, C. (2007). Algunas literariedades de Cien años de soledad. En Cien años de soledad (pp. xcvii-cxxvi). Madrid: Alfaguara; Real Academia Española; Asociación de Academias de la Lengua Española.

Harss, L. (1966). Los nuestros. Buenos Aires: Editorial Sudamericana.

Llacer Lorca, E. V. (2001). Historia novelada o novela histórica: El general Bolívar en el laberinto de García Márquez. Revista Hispánica Moderna, 54(2), 427-436.

Mahieux, V. (2011). Urban Chroniclers in Modern Latin America: The Shared Intimacy of Everyday Life. University of Texas Press.

Martin, G. (2009). Gabriel García Márquez, una vida. Barcelona: Debate. 
Martin, G. (2012). The Cambridge Introduction to Gabriel Garcia Márquez. Cambridge: Cambridge University Press; eBook Collection (EBSCOhost). Recuperado de http://search.ebscohost.com/login.aspx?direct=true\&db=nl ebk\&AN $=451661 \&$ authtype $=$ shib\&site $=$ eds-live \&scope $=$ site\&custid $=s 9008655$

Mendoza, P. A. (1982). El olor de la guayaba: Conversaciones con Plinio Apuleyo Mendoza. (1 ed.). España: Bruguera. Moliner, M. (2007). Diccionario de uso del español. (3ed.). España: Gredos.

Rabassa, G. (1982). García Márquez’s New Book: Literature or Journalism? World Literature Today, 56(1), 48-51.

Ramos, J. (1989). Desencuentros de la modernidad en América Latina: Literatura y política en el siglo XIX. México: Fondo de Cultura Económica.

Real Academia Española. (2020). Desvirtuar. En «Diccionario de la lengua española»-Edición del Tricentenario. Recuperado de https://dle.rae.es/desvirtuar

Real Academia Española. (2019a). Ocurrencia. En «Diccionario de la lengua española»-Edición del Tricentenario. Recuperado de https://dle.rae.es/ocurrencia

Real Academia Española. (2019b). Mentira. En «Diccionario de la lengua española»-Edición del Tricentenario. Recuperado de https://dle.rae.es/mentira

Real Academia Española. (2019c). Resorte. En «Diccionario de la lengua española»-Edición del Tricentenario. Recuperado de https://dle.rae.es/resorte

Rotker, S. (1992). La invención de la crónica. Argentina: Ediciones Letra Buena.

Rueda, M. H. (2017). One Hundred Years of Solitude: From Colombia to the World and Back. Review: Literature and Arts of the Americas, 50(2), 170-177.

Samper, D. (1980). A mi que me esculquen. Barcelona: Editorial Pluma.

Sims, R. L. (2010). García Márquez’s Non-Fiction Works. En Cambridge Companion to Gabriel García Márquez (pp. 144-158). Cambridge: Cambridge University Press.

Sims, R. L. (2016). Felt History and Permutations of the Fictional, Real, and Autobiographical «I» in Gabriel García Márquez's Chronicle of a Death Foretold and Living to Tell the Tale. En Gabriel Garcia Márquez in Retrospect: A Collection (pp. 197-211). Estados Unidos: Lexington Books.

Sorela, P. (1988). El otro García Márquez: Los años difíciles. España: Mondadori.

Swanson, P. (2017). Pop Goes the Boom: One Hundred Years of Solitude and the Latin American New Novel. Review: Literature and Arts of the Americas, 50(2), 162-169.

Vargas, G. (1985). Sobre literatura colombiana. Colombia: Fundación Simón y Lola Guberek.

Williams, R. L. (1984). Gabriel García Márquez. Woodbridge: Twayne Publishers.

Williams, R. L. (1985). An Introduction to the Early Journalism of Garcia Marquez: 1948-1958. Latin American Literary Review, 13(25), 117-132.

\section{Notas}

1 Entre 1950 y 1952, García Márquez llega a publicar cerca de 400 entregas de La Jirafa, recopiladas junto al resto de su obra periodística por el investigador francés Jacques Gilard (García Usta, 2007, p. 35). Algunas de sus Jirafas podrían considerarse cuentos cortos o, como los llama Raymond Leslie Williams, "fictional anecdotes", cuyas historias intentan crear otro tipo de realidad (1985, p. 123). El nombre de su columna lo escoge debido a que ese es el apodo con que él llama en broma a su novia, con quien más tarde se casa, Mercedes Barcha, a quien por su esbelto cuello llama "la jirafa”. Al hacer una lectura de las Jirafas se nota cómo muchas de ellas tienen origen en los cables internacionales que el joven escritor leía, escogía y recortaba en su trabajo cotidiano. Esas noticias de actualidad le sirvieron como semillero temático de su columna, donde las comentaba, las aumentaba, las reinterpretaba y -en muchos casos- también les agregaba especulaciones.

2 El crítico Jerónimo Arellano ha estudiado cómo la crítica ha analizado el término "realismo mágico" a partir de diversas formas de "maravilla" y "encantamiento" (2015, p. xiii). Una premisa central ha sido que el "realismo mágico" es de cierta forma heredero de las "maravillas del Nuevo Mundo" descritas en las crónicas del descubrimiento y la conquista de los siglos XV y XVI. Es decir, este término equivaldría a una repetición del antiguo discurso colonial, pero en una 
nueva forma narrativa en la América Latina moderna y poscolonial. Arellano sostiene que los escritores que han sido descritos como realistas mágicos hacen algo más complejo que simplemente vestir el lenguaje de la maravilla de las crónicas coloniales con "ropa nueva" y, por esto, invita a hacer una reevaluación histórica y teórica de este concepto. Sobre el uso de lo mágico por parte de la crítica, Jerónimo Arellano recuerda cómo en su explicación de "lo real maravilloso" Alejo Carpentier sugiere que la combinación de lo maravilloso y lo ordinario produce un "estado límite”; en su discurso de aceptación del Premio Nobel de Literatura, García Márquez habla de cómo la realidad hiperbólica de sus trabajos da paso a un sentimiento de asombro; el crítico Franco Moretti considera al realismo mágico como un "torbellino" que "reaviva la maravilla" en un mundo de desencanto; Wendy Farris argumenta que el realismo mágico reencanta la forma narrativa particularmente al modo dominante del realismo de Occidente; Lawrence Weschler dice que la ficción del realismo mágico de América Latina es impulsado por un espíritu de la maravilla marginado; y Jean Franco afirma que el atractivo del realismo mágico fue que reencantó al mundo al incorporar a la literatura las creencias y prácticas populares como una forma de disenso de la racionalidad posterior a la Ilustración (2015, p. xxiv).

3 La crítica Vivianne Mahieux ha usado el término "retórica de la accesibilidad" para describir a un tipo de textos, como los de los periódicos, que llegan a un público amplio (2011, p. 22). Esa "accesibilidad” deja al autor de estas formas escriturarias vulnerable ante los acontecimientos imprevistos de la vida pública. "He or she must be willing to comment on the unexpected with originality and speed" (Mahieux, 2011, p. 23).

4 El periodista escritor Héctor Rojas Herazo recuerda cómo García Márquez escribía una novela mientras trabajaba dentro del diario El Universal: "(García Márquez) es hoy por hoy el mejor cuentista nacional que en los intermedios de su trabajo diarístico ha ido preparando con especial tenacidad una novela de poderosa e inquietante inspiración” (Flores Sierra, 1989, p. 8).

5 En Crónica de una muerte anunciada (1981) hay huellas de sus pisadas como reportero: el formato de esta narración, como lo apunta el crítico y traductor Gregory Rabassa, es bastante periodístico e, incluso, el narrador se incluye como un personaje periodista dentro de la trama, al viajar a un pueblo para investigar, hacer entrevistas y reconstruir los detalles del asesinato del protagonista, Santiago Nassar (1982, p. 49). La génesis de Crónica es también periodística: en su biografía sobre García Márquez, el crítico Gerald Martin cuenta que en 1951 el joven periodista recibió la noticia de que un amigo de su familia, Cayetano Gentile, había sido asesinado en la ciudad de Sucre (2009, p. 182). En sus memorias, García Márquez explica que ante el suceso se desplazó a Sucre y recopiló los datos para escribir un texto. Sin embargo, su madre le pidió que no lo escribiera por respeto a la familia Gentile, por lo menos mientras la madre de Cayetano estuviera viva (García Márquez, 2002, p. 460). García Márquez sostiene que cumplió con su promesa y que es por eso que solo hasta años más tarde, en 1981, publicó su crónica del asesinato, pero no como reportaje, sino como una ficción. En otra de sus obras, El general en su laberinto (1989), García Márquez hace conjeturas a partir de datos históricos y el texto puede ser leído como un "reportaje actualizado del pasado" (Llacer Lorca, 2001, p. 427). Algunas de sus obras, como Relato de un náufrago, La aventura de Miguel Littín clandestino en Chile y Noticia de un secuestro pueden ser catalogadas como reportajes literarios.

6 García Márquez explicó que en estos contactos con Vinyes, tanto él como el resto de sus colegas se enseñaron a leer y a escribir los unos a los otros (1994b, p. 11).

7 En su autobiografía, García Márquez confesó cómo decidió tomar como pseudónimo el nombre de uno de los personajes de la novela Mrs. Dalloway: "No lo pensé dos veces: Septimus, tomado de Septimus Warren Smith, el personaje alucinado de Virginia Woolf” (2002, p. 433).

8 García Márquez vuelve famoso el término "mamagallismo", que incluso utiliza cuando recibe el premio de novela Rómulo Gallegos, en 1972. Este es un tipo de humor que aplica "una doble dosis de sorna a la manera con que se mira el mundo" (Samper, 1980, p. 374). Daniel Samper explica que el concepto tiene su origen en las peleas de gallos, en las cuales se muerden las patas del animal y se les aplica aguardiente para causarle escozor y volverlo más agresivo (1980, p. 374). Este es un tipo de humor oral que García Márquez practicó con un conjunto de amigos, el llamado Grupo de Barranquilla, y que trasladó a sus textos escritos.

9 Hubo tres columnas que tienen que ver con la ficción alrededor de la marquesa que fueron publicadas en otros días: el jueves 11, el lunes 22 y el martes 23 de mayo de 1950. Posteriormente, la marquesa es mencionada marginalmente en sus columnas del 14 de julio y 20 de septiembre de 1950, así como en su Jirafa del 14 de julio de 1951.

10 El crítico Robert Sims explica que los “refritos" son un tipo de texto que da seguimiento a una noticia y que, en la obra de García Márquez, representa esa conexión entre sus trabajos de ficción y de no ficción (2010, p. 144). En esos textos-conexión hay hibridaciones o traslapes de distinto grado entre el periodismo informativo y la literatura creativa. El término "refrito", generalmente usado en un sentido peyorativo, es ampliamente conocido en el argot periodístico latinoamericano y evoca la idea de refreír o recalentar una noticia que se ha enfriado por su sobreexposición en la prensa. Los "refritos" de García Márquez son versiones de noticias que han sido publicadas previamente, pero a las que el escritor les agrega contexto, detalles, fuentes y, frecuentemente, de una forma subrepticia, opiniones. Es decir, el "refrito" garciamarquiano es una noticia reescrita, resemantizada e intensificada con las intenciones del autor. Uno de sus más célebres es Relato de un náufrago, un texto periodístico que se ha convertido en parte de su canon literario. 